UDC 76 7.034(450) 7.047(282.2) 001.891.34 7.049

\title{
LEONARDO DA VINCI'S HIDDEN IMAGES. "THE ARNO VALLEY LANDSCAPE" (1473). MYSTIC SILENCE 540 YEARS LONG...
}

\author{
(C) V. A. Melnikov*, D. A. Ilyamova \\ Ufa State Petroleum Technological University \\ 195 Mendeleeva street, 450080 Ufa, Bashkortostan, Russia. \\ Phone: +7 (917) 7523475 . \\ E-mail:v.a.m.lera@mail.ru
}

This paper is devoted to Leonardo da Vinci's "The Arno Valley Landscape". The historical aspect of the subject under study has been considered, as well as the methodological issues in learning the professional drawing techniques in the framework of Leonardo's ten attributes of sight and the Thinking through Drawing methodology. Our approach allows formulating the figurative and artistic component of the masterpiece and find out Leonardo's hidden messages, full of mystics and symbolism.

Keywords: Leonardo, "The Arno", analytics, images, metamorphoses, universality, time, heritage.

When a key is found, you needn't break down the door.

Publius Syrus

\section{The History of the Subject}

Works of art and science created by Leonardo da Vinci, this titan of the Renaissance, have been considered in many fundamental books that reveal his genius in the context of the world culture. The list of authors includes Giorgio Vasari, Eugène Müntz, Carlo Pedretti, Marco Cianci, Fritjof Capra, Frank Zöllner, Stendhal, Sigmund Freud, Dmitry Merezhkovsky, Vladimir Lazarev, Aleksey Dzhivelegov and others. Traditionally, all of them represent Leonardo's art in its pictorial aspect by masterpieces such as "The Last Supper", "John the Baptist", "La Giokonda", etc., resulting from consummate mastery of "Leonardo's intellectualism" [1, p. 43], whereas the "cause" must be sought for in his "creative laboratory" called GRAPHICS. Among a tremendous number of drawings, sketches and rough drafts created by the Master, more thorough attention and closer investigation should be focused on a small drawing (less than A4 in terms of the present day) done by Leonardo da Vinci at the age of 21.

So let us take "The Arno Valley Landscape", 1473, pen and ink over a partially erased pencil sketch, 190x285 mm, Florence, Uffizi Gallery, with the inscription made in Leonardo's usual mirror writing, "On the day of St. Mary of the Snow, August 5, 1473". "By giving the precise date and thus glorifying the definite event, Leonardo creates an illusion of snow falling in August, a phenomenon both natural and unusual, something like a synthesis of two opposite seasons" [12, p. 29]. 


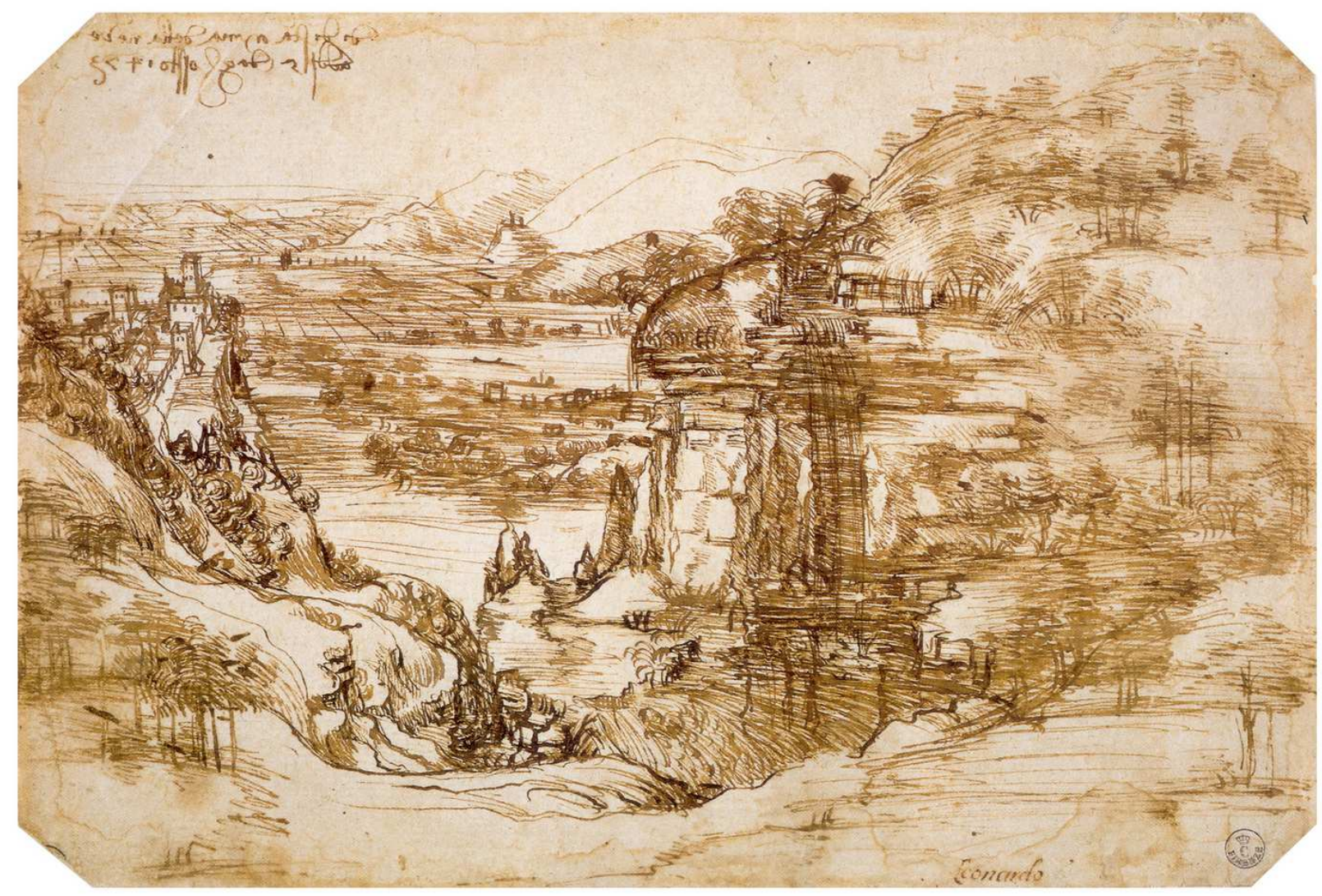

Leonardo da Vinci. "The Arno Valley Landscape”, 1473

Some researchers interpret this work either "as an evidence of his attachment towards places where he spent his childhood" [11, p. 7] or as a rough draft of the topographical situation for future hydraulic structures in the Arno River bed...

Eugène Müntz wrote, "... and nevertheless, the landscape (evidently, this is a sketch from nature) lacks compositional arrangement and conception; it has something uncertain, like in many other works of the Genius, so difficult to fit into any clear-cut categorical scheme of expressiveness" [2, vol. 1, p. 42].

Evidently, it is not merely a "sketch from nature"; the drawing was rather executed from imagination on the basis of a "real" historical place near Florence.

"The Arno Valley Landscape", the masterpiece of world's graphics, may quite become a "key" to understanding the worldview of "divine Leonardo" [1, p. 26] combining, in a single drawing, a scientist, researcher and gifted drawer who thinks using the laws of figurative knowledge and stupendous images and creates mystical implications and hidden meanings that still continue to excite the minds and feelings of both scientists and onlookers all over the world. While penetrating deeper into the plastic space of the graphic sheet, you reveal, step by step, the harmonious logical system of the Universe which proves, in Lazarev's opinion, that Leonardo was the first artist to "convert the act of creating into a conscious and rational process" [1, p. 42].

This assumption is supported by the fact that "this study was drawn in pencil from nature and then outlined in ink in his studio" [6, p. 8], i.e. at first the young artist had attentively examined the spatial situation catching en plein-air the expressive features of the recognizable landscape and then subjected the outdoor drawing to "critical intellect-based modification" [1, p. 29]. According to Va- 
sari, this drawing was made "... with great skill due to the most extraordinary observations" $[6, \mathrm{p}$. 222].

\section{Ten Attributes of Sight and Thinking through Drawing Methodology}

This art-work is essentially an unparalleled methodological "manual", through which you can comprehend the unique pictorial and plastic laws:

1) determination of the form and compositional idea;

2) spatial orientation;

3) structure - figurative;

4) perspective;

5) rhythm - proportions - scale;

6) forming;

7) movement;

8) tonal and plastic arrangement;

9) energy of tone;

10) time;

11) images, visual sequence transformation and metamorphose;

12) spirituality [7, p. 90-91].

Everything implied in this landscape drawing in Leonardo's younger years was fully reflected in his mature-age notes: "He put every element in an assigned place dividing the creative process into several consecutive steps and exactly formulating objectives and goals that face an artist" [1, p. 42]. Ten "attributes of sight" - brightness, darkness, colour; substance, form, place; remoteness, nearness; motion and rest [1,438*410, p. 201] have become undeniable axioms, "reminding [painter] of the rule and way, according to which he must imitate in his art all these things created by nature to decorate the world" [8, 520.Ash.I.22v., p. 125]. Frankly speaking, we should take into consideration a certain strange habit with the Master to hide the truth in his numerous notes, thus confusing the researchers; it may well be that in our specific case "ten attributes of sight" are placed in a sequence he was the only man to know.

To continue the Leonardo's course, it is worthwhile to add some graphic language elements, i.e. dot, line, stroke, spot, and build a logical chain of regularities in terms of the scientific method "Thinking through Drawing" [7; parts I, III]:

"place" - spatial orientation: dot, line;

"form" - structure, vectors, spirals: dot, line, junctions;

"remoteness, nearness" - perspective, rhythm, scale: line, junctions;

"substance" - proportions, forming: line, junctions, stroke;

"motion and rest" - movement, time: stroke, spot;

"brightness darkness" - tonal arrangement, energy of tone, volume: spot;

"colour" falls into a category of painting, and it is quite appropriate to take here the term "image" - image, metamorphoses, spirituality.

The systemic approach used in the methodological study reveals a hidden image-bearing mystic "stratum" of the Leonardo's piece of graphics full of enigmatic metamorphoses and fantastic symbols.

\section{3. "The Arno": Is it a Landscape or Images?}

The drawing is composed of two image-bearing psychological parts: 
the left one shows the history of Leonardo's childhood and includes the images of father, mother, stepmother, hawk and cat;

the right one represents the reality of the surrounding world; images of eagle, man's profile, warrior and beast of prey.

The work also reveals the philosophical definition of "time": the left part means pacification and tension deep in the past, whereas the right one depicts aggression, and at the same time optimism towards an unknown future.

In fact, we have discovered 24 image-bearing symbolic objects during our investigation, but now let us consider only eleven of them.

\section{The Father's Family}

In the left part of "The Arno Valley Landscape" we see two figures: a forward-facing young woman next to a portly middle-aged man with a beard turned in profile. They are engaged in a mute dialogue. No doubt, these are Leonardo's stepmother Donna Albiera and his father Signor Piero da Vinci.

The Genius of the Renaissance was figlio non legiptimo - "illegitimate son" [1, p. 14] and "was adopted into his grandfather's family till the age of five" [4, p. 93], where he spent his childhood. The Master shows an idyllic relationship between father and his young wife - there is a cat in front of her feet as a symbol of well-being and fireside comfort.

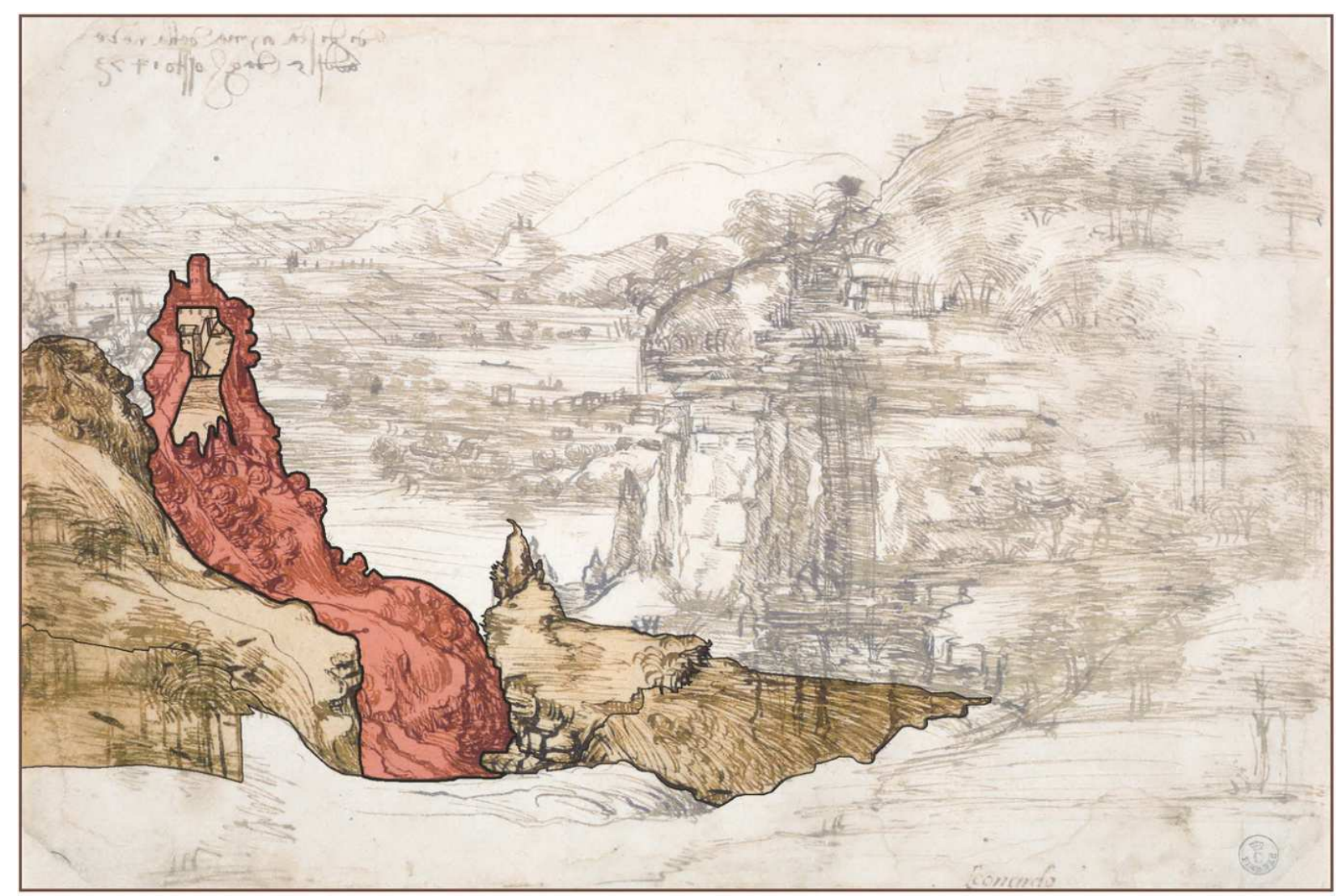

Structure I. "The Father's Family".

Leonardo interprets the female image smartly and endows it with the traits of a woman pending motherhood, for "his young stepmother Albiera has undoubtedly taken the mother's place in his thoughts" [4, p. 93]. 


\section{Mother Katarina}

Freud wrote, "He had two mothers: one of them was his actual mother Katarina whom he lost between the age of three and five, and Dona Albiera, his young tender stepmother and his father's wife" [4, p. 83]. Leonardo would be inconsistent as a son if he had not touched on his own mother's image.

Let us turn the drawing through 180 degrees, and instead of the static peaceful "holy family" we shall see the female head thrown back and the face distorted with horror, fear and despair that reveals the tragedy of the woman who gave birth to the Genius of the Renaissance.

The fact that it is precisely the Katarina's image is ascertained by the hawk-like bird that symbolizes motherhood according to local beliefs.

The figures of the woman on bended knee and the bird are merged together in one syncretic whole visualizing the dramatic situation through a dynamic pose.

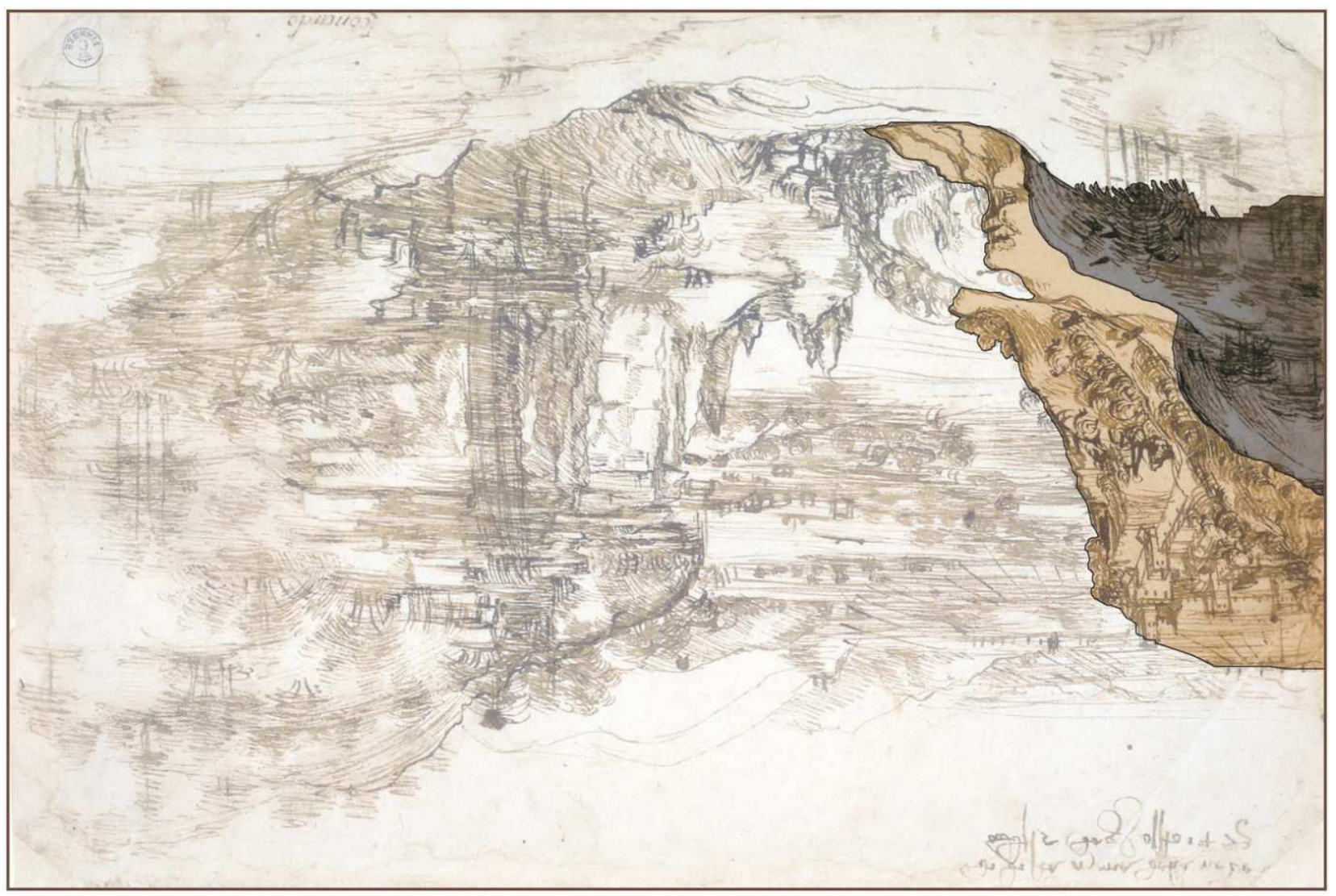

Structure II. "Mother Katarina”.

\section{The Hawk and the Eagle}

"I was probably fated to deal with a hawk in such a substantive manner, for it occurs to me from the earliest childhood recollections how I was lying in my cradle and a hawk flew down to me, opened my mouth with its tail and pushed my lips many a time" [8, F.65v.]. 


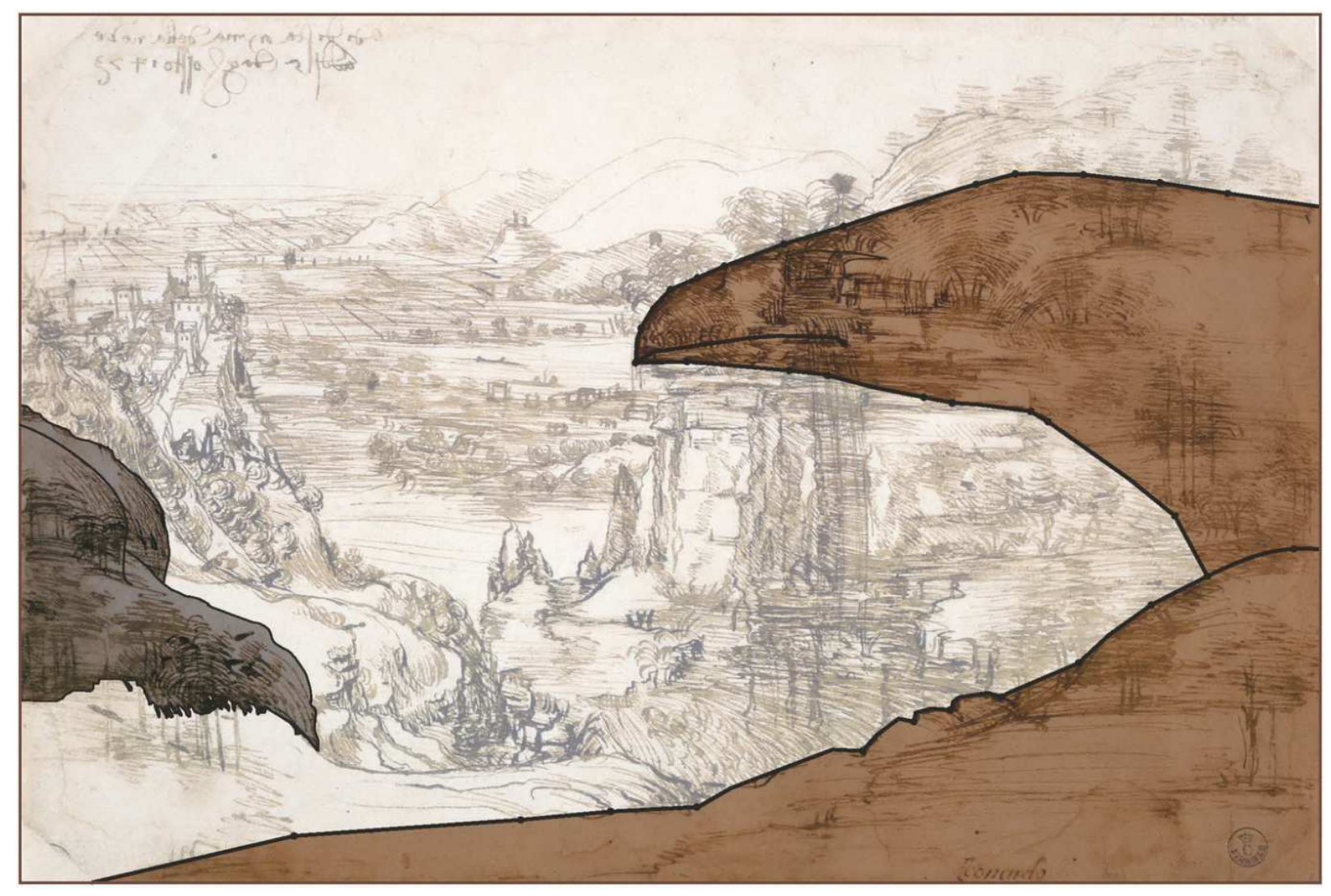

Structure III. "The Hawk and the Eagle".

The artist places the image of the bird in the left angle of his composition, where he reveals the entire history of his dramatic childhood.

The hawk in a static pose with its wings folded and beak pointed down embodies virtue and good intentions in the destiny of the depicted people, as emphasized by gentle rhythms and smooth linear outlines.

The interpretation of the image points out the fact that Leonardo "can likened himself to a nestling hawk" [4, p. 50], and consequently, this can be treated as a root of his all-consuming dream of flight, to which he devoted the most interesting scientific investigations. "As if a key to all his accomplishments and all his misfortunes is hidden in his childish fantasy about the hawk" [4, p. 117].

The right part of the work contains a huge eagle silhouette. An extended wing, a raptorial beak and clear-cut forms create a dominant image with expressive lines in the compositional structure of the drawing. "For the first time the big bird will direct its flight off the back of its big swan (cecero) filling the world with amazement, all the writings with its glory and the nest where it was born with eternal honour" [1, p. 24]. The mountain depicted in the landscape is most likely to be Big Swan Mountain ("Monte cecero") near Florence.

The large-scale image of the bird flying above the earth creates a tremendous depth of the pictorial and plastic space in "The Arno Valley Landscape", as if Leonardo would like to say that his genius enjoys the protection of this proud bird, a symbol of power over the world. 


\section{The Beast of Prey, the Cat and the Sphinx}

We do not know the Leonardo's motive for using the images of animals; nevertheless, their presence in the compositional and semantic structure of the drawing seems to be quite organic.

A ferocious beast of prey located in the right half of the drawing is the key element expressing the utmost aggression with the horrible bare teeth ready to seize the prey in the left part of "The Arno Valley Landscape".

In counterbalance to the impending danger and as a symbol of invincibility in the face of circumstances, we see a lying cat (down the centre) with its eye half-closed.

Its localization in the compositional structure is highly informative, for it serves as a "buffer zone" between peace and war, good and evil.

The cat's silhouette in the form of a sphinx (up the centre) appears to be enigmatic and gives food for thought (an assumption about the Leonardo's secret journey to the East).

But the chronology of his life is inexorable, and this is only the result of "young artist's fantasies indeed..." [4, p. 105].

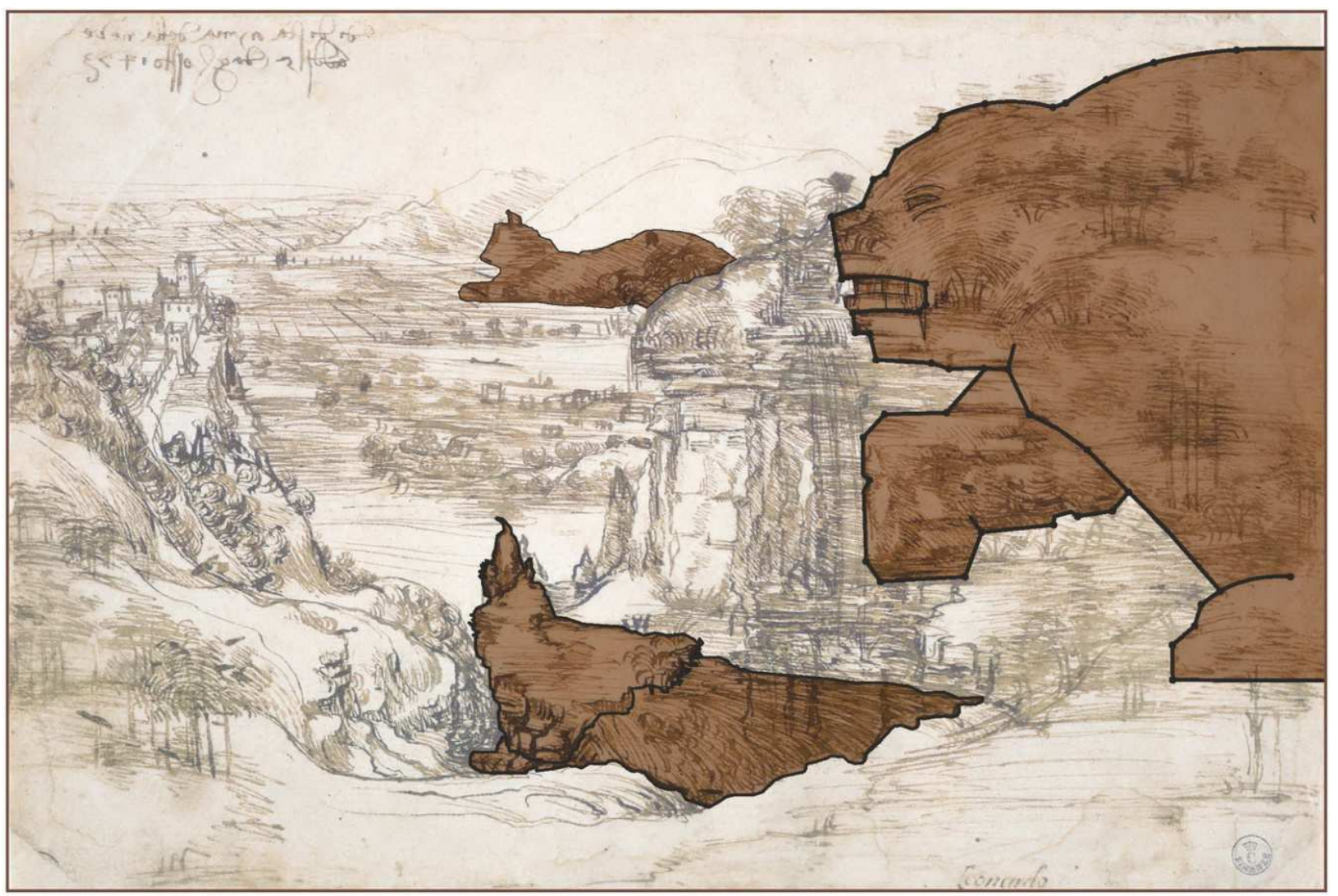

Structure IV. "The Beast of Prey, the Cat and the Sphinx".

\section{The Man's Profile}

The right part of the landscape composition concentrates large-scale figures. These are the beast of prey, the eagle and the third character - a man shown in profile.

He is well "read" under the reduced format: the light spot in the form of a human head occupies almost one third of the drawing. 
The Greek profile with a straight nose, lips pressed tightly, a square chin, an intent gaze and luxuriant flowing hair apparently represent a grotesque image of some well-known or historical figure.

History keeps it secret.

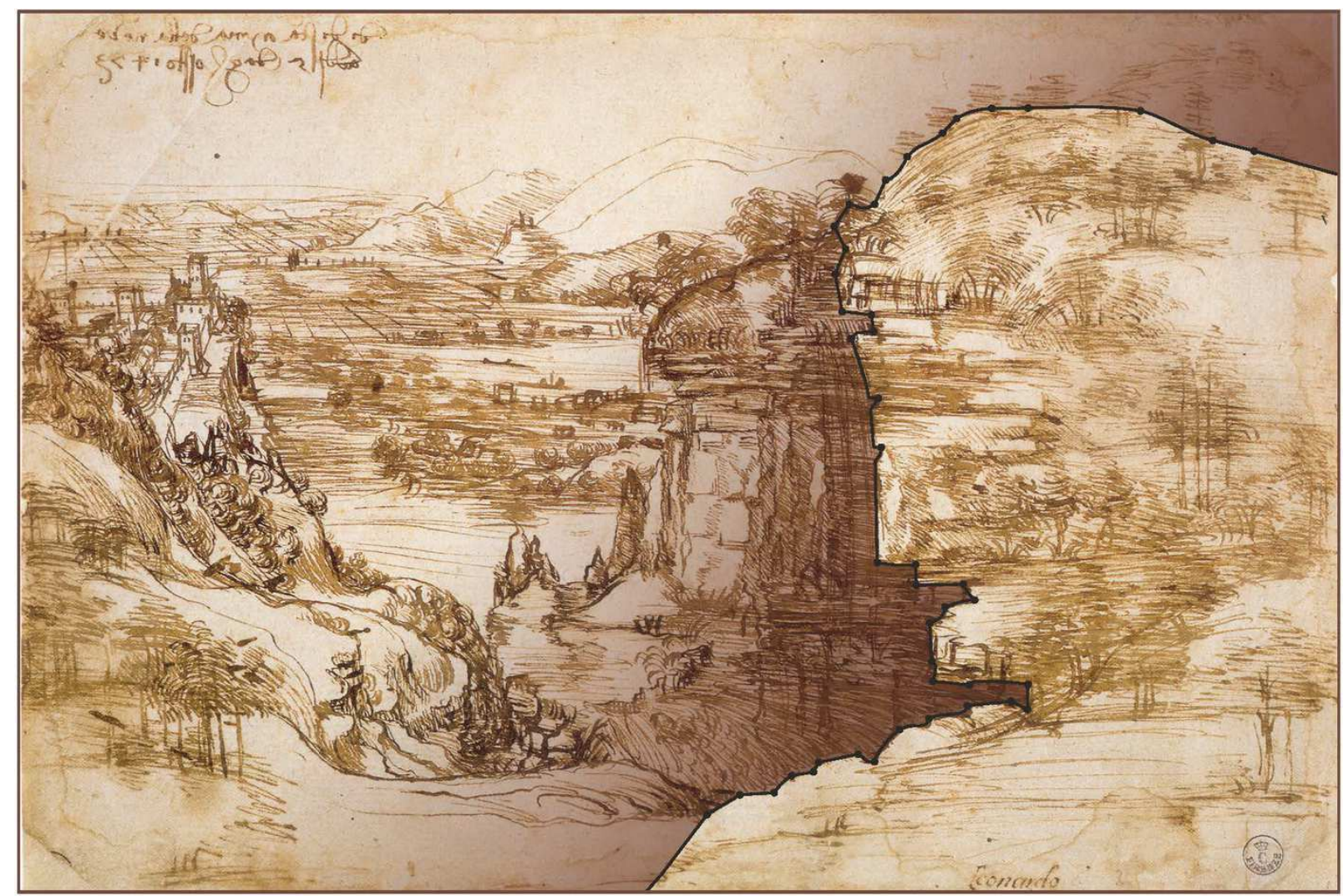

Structure V. “The Man's Profile”.

\section{Warrior}

Yet, it is still far from the end of metamorphoses.

In approximately 1472 Leonardo created the drawing called "The Profile of a Warrior in Armour and Helmet" (metal point on prepared paper, 285x207 mm, London, British Museum) [3, p. 93].

"... With his drawing hands, he could so perfectly express his intentions that his arguments gained the victory and his reasons confused any stubborn man" [6, p. 211]. The impressive drawing is performed in practically the same format as "The Arno Valley Landscape": the longer side (285 $\mathrm{mm}$ ) completely coincides, and the short one differs only by $17 \mathrm{~mm}$.

The format "module" enabled us to bring drawings into coincidence with the only exception of inclining the warrior's head to 18 degree angle, and these two artworks merged together perfectly well. It is hard not to notice that the helmet visor resembles the eagle head outlines, and the warrior's general silhouette fits almost ideally into the shape of Big Swan Mountain creating quite a logical extension of the right part of the composition - the beast of prey, the eagle and the warrior as symbols of his time, aggression, strength and power. 

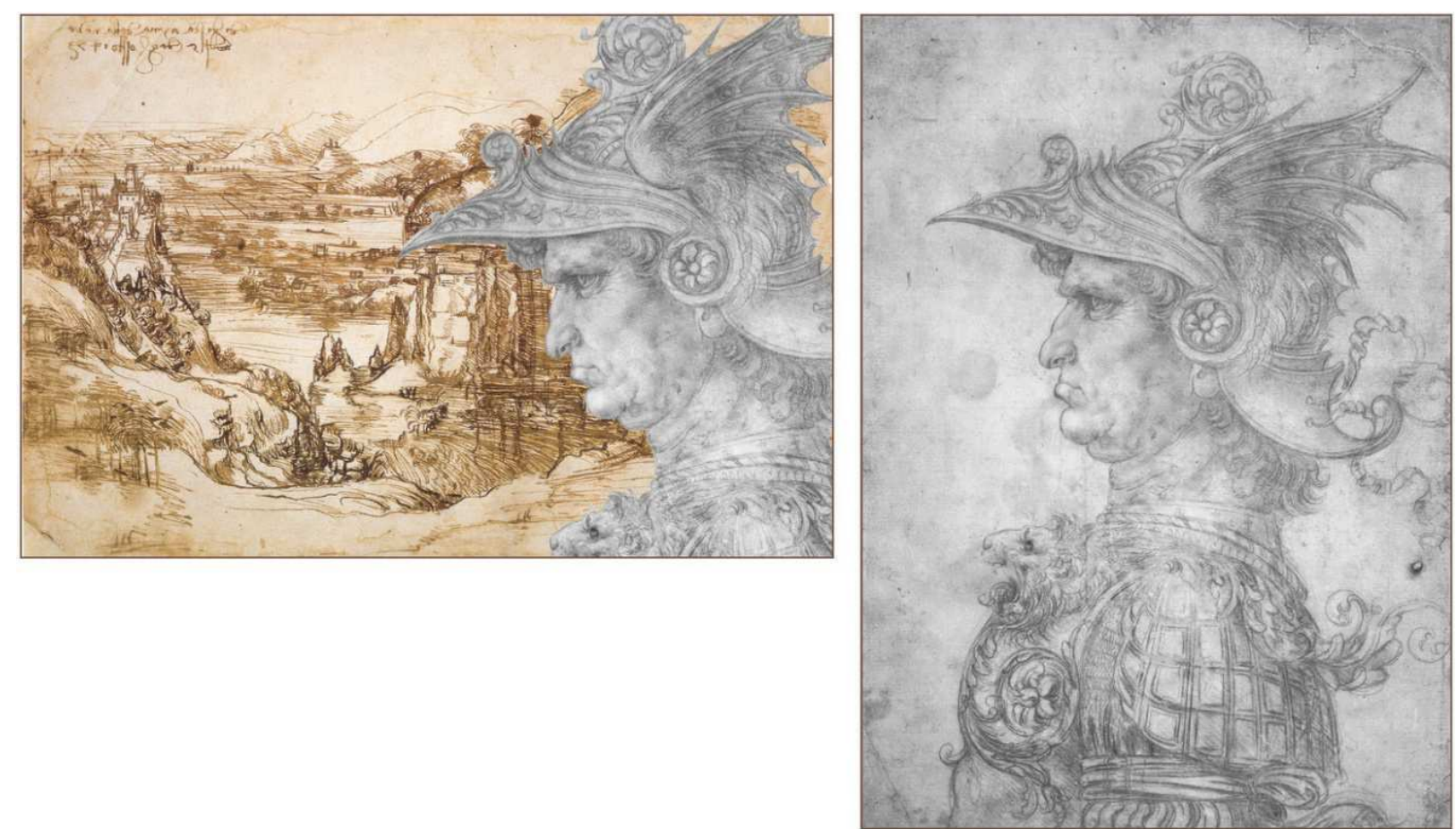

Structure VI. "The Warrior",

"The Profile of a Warrior in Armour and Helmet", 1472.

There is one "attribute of sight" in the Leonardo's drawing that shows the perfection of his spatial reasoning. The Master defines "remoteness, nearness" as a scale which can be excellently "read" in the spatially distributed image-bearing structures in accordance with the law of perception: bigger - closer, and smaller - farther away [7, p. 36]. In structure I the small cat of a bigger size seems closer to us than the bigger figures of a smaller size. An analogous regularity is seen in other groups arranged spatially as the distance increases: II - the hawk and the woman; III - the beast of prey, the cat and the sphinx; IV - the eagle and the hawk; V - the man's profile and the warrior. In the latter case the variable metaphoricity of the images (one replaces the other) takes place when we change the dimensions of the drawing from $\mathrm{A} 6$ to $\mathrm{A} 2$.

\section{Giuseppe Arcimboldo, Salvador Dali}

Leonardo da Vinci's art and science heritage has undoubtedly made a great impact on the world culture. The Master's genius has set initial vectors to trends and styles in art, though it was understood only by those talented artists who managed "to read" Leonardo's [ciphered] truth, among them Giuseppe Archimboldo (1530-1593) with his "pictures full of fantasy and visual metaphors" [5, p. 58] and Salvador Dali (1904-1989), the founder of surrealism.

Arcimboldo got acquainted with Leonardo da Vinci's drawings in his early years, and "we can only imagine how deeply they impressed the young artist" [5, p. 10].

In his fantastic artworks, Arcimboldo was guided by the "key" found in "The Arno", and "it seems as if Leonardo himself directed the painter's hand" [5, p. 34].

At the age of 15 Dali studied the works of the great masters of the past and published articles. It is not improbable that the young talented drawer stored, somewhere in the subconscious mind, the image of "The Arno Valley Landscape". 


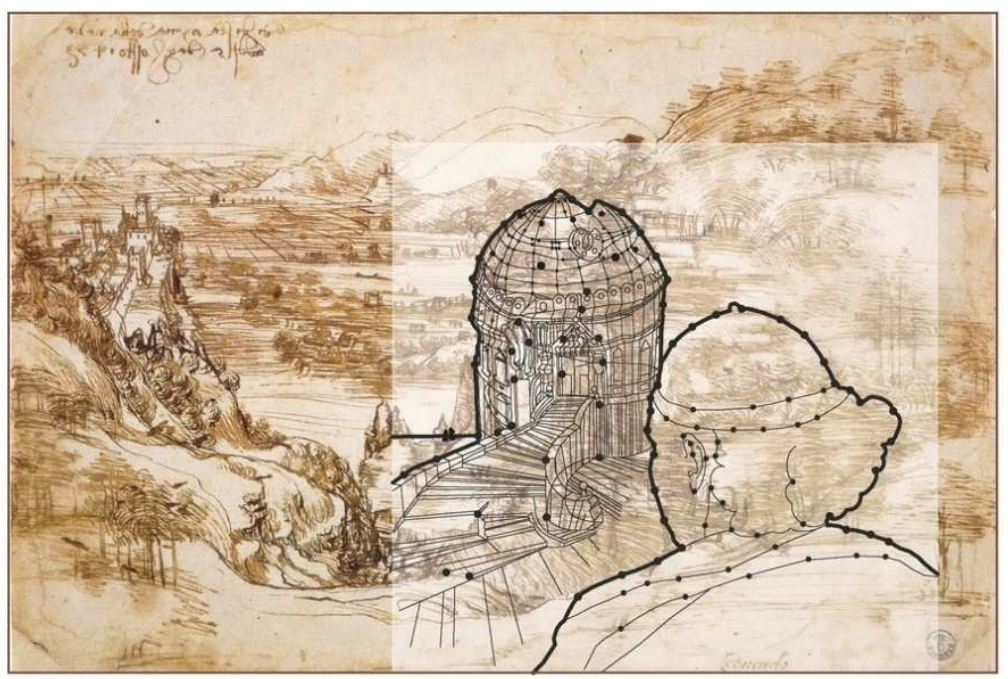

Structure VII. "Salvador Dali”

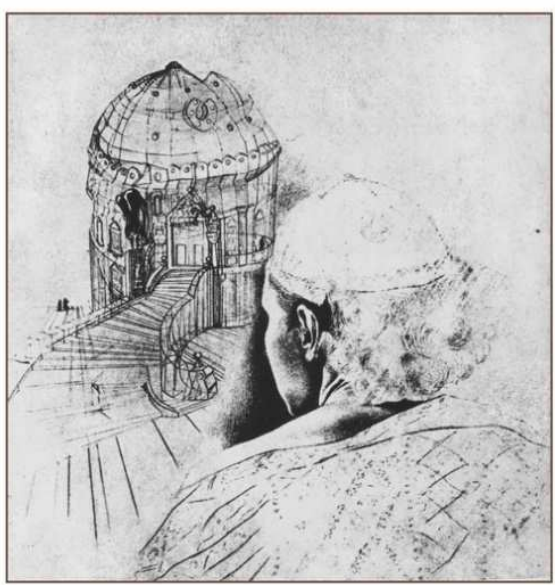

"Geodesic Portrait of Gala"

Dali's art is permeated with the perfection of the High Renaissance ideals, behind which is the "Leonardo's creative personality" [1, p. 27]. In "Five Thoughts on Art" we read, "(5) Leonardo da Vinci proved that pictorial art is above all other arts, since it addresses the eye, the noblest and most divine of our organs" [9, p. 16]. The Genius of the Renaissance opened the eyes of the Genius of the 20th century: Dali "grasped" the surrealistic aspect of "The Arno Valley Landscape"!

Attention he paid to studying the Leonardo's masterpiece is corroborated by his own drawing "Geodesic Portrait of Gala" (1936, pencil on paper, 38x33 cm, private collection) [10, p. 270]. By comparing or superimposing both drawings, we see how Big Swan Mountain coincides with the "rotunda-shaped head". Dynamic linear rhythms at the feet of the giant rock are harmoniously combined with a smooth banister curved not spontaneously, but following "control points" and "figurative".

\section{Conclusion}

Our investigation into "The Arno Valley Landscape leaves three key questions unanswered:

1. What had happened with Leonardo in his "casa sua", when after secluding himself from outside world for an unknown period of time (hours, days, weeks...) he at last brought to light his brilliant artwork, "one of the earliest landscapes in the history of art" [3, p. 10]?

2. Was the Arno Valley Landscape the "reference start point", thanks to which "Treatise on Painting" by Leonardo da Vinci appeared a quarter of a century later?

3. What is this: either a landscape "woven" of images or images that "created" the landscape?

Nevertheless, Leonardo da Vinci' masterpiece has undoubtedly made a miracle happen: this small drawing has turned over the tremendous world of fine arts.

First, it becomes a pioneer piece of graphics in the world practice that makes drawing an independent artwork.

Second, a synthesis of sciences and arts lays the solid ground in the compositional pictorial and plastic space arrangement of "The Arno". "He has elaborated a complex system of rules and laws seeking to be absolutely true" [1, p. 42].

Third, it is like a universal manual on drawing knowledge, with the "laws" giving "a powerful impetus for living creativity" [1, p. 42]. 
Fourth, it is for the first time that Leonardo da Vinci formulates, within the conditional plastic space of the graphic sheet, his philosophical understanding of MOTION [7, p. 30] and TIME [7, p. 32].

Fifth, Leonardo shows excellence of execution, brilliant technique and "the most rigorously rhythmed" [1, p. 20] "shape" and "space" of his composition. The drawing is formed by the utmost "lean graphic language" consisting of "dot, line, stroke, and spot".

Sixth, in addition to sketching from nature, Leonardo introduces an "author's understanding" of the compositional arrangement of the artwork with its figurative and informative subtext, and "it is precisely the point that begins the intellectualistic trend in the development of the European art" [1, p. 42].

Seventh, hidden or veiled images implied in pictorial sequence of "The Arno Valley Landscape" do not reveal themselves at first glance, but require an artistic analytical approach to understanding the work serving as the basis for the advent of new trends in the world art.

"The Arno Valley Landscape" has become a borderline, beyond which he begins to move forward looking fearlessly into the future and not turning his face towards the past. He released himself from sad feelings of an unhappy child deprived of mother's love. Only his genius, with "crystal-clear clarity" [1, p. 16] of the unique mind and great capacity for work became his programme credo in science and art that enabled Leonardo da Vinci to make his way up to Olympus of the world culture.

"CERCA TROVA" (seek and you shall find)

Computer graphics has been performed by architect Ksenia Ivanova, a former student to V. A. Melnikov.

Translated into English by Anna Maslova; e-mail: anna@anrb.ru

\section{REFERENCES}

1. Book on Art by Master Leonardo da Vinci, Painter and Sculptor of Florence / Ed. A. G. Gabrichevsky. Moscow: OGIZ-IZOGIZ, 1934. 384 pp.

2. Müntz E. Leonardo da Vinci. Artist, Thinker and Man of Science. Moscow: BMM, 2007. 256 pp.

3. Zöllner F. Leonardo da Vinci. Moscow: Taschen, 2003. 96 pp.

4. Freud S. Leonardo da Vinci and a Memory of His Childhood. Saint Petersburg: Azbuka, 2012. 224 pp.

5. Kriegeskorte W. Giuseppe Archimboldo. Moscow: Taschen, 2002. 80 pp.

6. Vasari G. Life of Leonardo da Vinci. Moscow: Eksmo Publ., 2005. 640 pp.

7. Melnikov V. A. Thinking through Drawing. Ufa: Neftegazovoe Delo, 2007. 102 pp.

8. Leonardo da Vinci. Selected Works: in 2 vol. Vol. 2. / Ed. A. K. Dzhivelegov, A. M. Efros. Moscow: Artemy Lebedev Studio, 2010. 480 pp.

9. Dali S. 50 Secrets of Magic Craftsmanship. Moscow: Eksmo, 2002. 272 pp.

10. Descharnes R., Nevers J. Salvador Dali. Moscow: Taschen, 2004. 780 pp.

11. Romei F. Leonardo da Vinci. Moscow: ROSMEN, 1998. 64 pp.

12. Vezzosi A. Leonardo da Vinci. Art and Science of the Universe. Moscow: Astrel Publ., 2001. 160 pp. 


\section{СКРЫТЫЕ ОБРАЗЫ ЛЕОНАРДО ДА ВИНЧИ. «ВИД ДОЛИНЫ АРНО» (1473): МИСТИЧЕСКОЕ МОЛЧАНИЕ ДЛИНОЙ В 540 ЛЕТ}

\section{(C) В. А. Мельников*, Д. А. Ильямова}

Уфимский государственный нефтяной технический университет Россия, Республика Башкортостан, 450080 г. Уфа, ул. Менделеева, 195.

E-mail:v.a.m.lera@mail.ru

Статья посвящена рисунку «Вид долины Арно» Леонардо да Винчи. Рассматривается исторический аспект предмета исследования. Затронуты вопросы методологии профессионального изучения предмета «Рисунок» с позиции «10 областей действия» Леонардо и методики «Мыслить рисунком». Аналитический подход позволил сформулировать образно-художественную составляющую произведения и обнаружить скрытый Леонардо подтекст - полный мистики и символизма.

Ключевые слова: Леонардо, «Арно», аналитика, образы, метаморфозы, универсальность, время, наследие.

Просьба ссылаться на эту работу как: Мельников В. А., Ильямова Д. А. Скрытые образы Леонардо да Винчи. «Вид долины Арно» (1473): мистическое молчание длиной в 540 лет // Российский гуманитарный журнал. 2013. T. 2. №3. С. 216-227.

\section{ЛИТЕРАТУРА}

1. Книга о живописи мастера Леонардо да Винчи, живописца и скульптора флорентийского / Под ред. А. Г. Габричевского. М.:ОГИЗ-ИЗОГИЗ, 1934. 384 с.

2. Мюнц Эжен. Леонардо да Винчи. Художник, мыслитель и ученый: в 2 т.: пер. с англ. М.: БММ, 2007. 256 с.

3. Цельнер Ф. Леонардо да Винчи. М.:Taschen, 2003. 96 с.

4. Фрейд 3. Воспоминания Леонардо да Винчи о раннем детстве. СПб.: Азбука, 2012. 224 с.

5. ригескорте Вернер. Джузеппе Арчимбольдо. M.: Taschen, 2002. 80 с.

6. Вазари Дж. Жизнеописание Леонардо да Винчи. М.: Эксмо, 2005. 640 с.

7. Мельников В. А. Мыслить рисунком. Уфа: Нефтегазовое дело, 2007. 102 с.

8. Леонардо да Винчи. Избранные произведения: в 2 т. Т. 2. / Под ред. А. К. Дживелегова, А. М. Эфроса. М.: Студия Артемия Лебедева, 2010. 480 с.

9. Дали С. 50 магических секретов мастерства. М.: Эксмо, 2002. 272 с.

10. Дешарн Робер, Нере Жиль. Сальвадор Дали. M.: Taschen, 2004. 780 с.

11. Ромеи Ф. Леонардо да Винчи. М.: РОСМЭН, 1998. 64 с.

12. Веццози А. Леонардо да Винчи. Искусство и наука Вселенной. М.: Астрель, 2001. 160 с.: ил. 